\title{
Materia Medica
}

Failing

Tracey Delaplain, MD, FACOG

Center for Women's Health, Reno, NV, USA.

KEY WORDS: aging; mental status; primary care; handicaps; geriatrics. J Gen Intern Med 26(7):819

DOI: $10.1007 / \mathrm{s} 11606-010-1617-1$

() Society of General Internal Medicine 2010

I 'm sitting in a doctor's waiting room. My daughter gives me a handful of pills every day so I suppose it would not be unusual to visit one of my doctors every few months. I have a doctor for my failing heart, my degenerating eyes, my deaf ears, and I guess this doctor takes care of the rest. My daughter thumbs through a magazine; I am envious, having not been able to read for three years. Maybe I'll crawl out of this chair and find my own magazine to look at. Or not. Why do they put chairs like this in a doctor's office? They are impossible to get up from and I'm not going to ask for help. "Do I know that person on the TV?" I ask. "Mom, I'm trying to read!" she barks. I try to imagine the speaker's face without black holes. I tilt my head until I can focus on different parts of her face and then try to put all the pieces together in my head to form a whole. She's a little clearer than a Picasso painting but not much. I ponder the image-if I could just smooth out the lines of that face, I think I could remember her name. The TV volume is low so hearing her voice is impossible, and I can't read her lips. So I sit.

My name is called by a voice I've heard, but cannot place. "Why don't nurses wear name badges anymore?" I blurt, but she's not looking at me. She directs all questions to my daughter. Doctors and nurses used to speak to me, not about me. I can't hear their questions so they have to repeat themselves; that annoys them. The nurse leaves the room with my daughter. "I want to talk to the doctor first today," my daughter says over her shoulder. I know that tone in her voice. She's mad at me again.

I remember yesterday vividly. I told her that someone had taken my red blouse. In the darkness of my bedroom, my clothes are all the same gray-brown color; I don't recognize them when they're moved from their usual places. Imagine your closet. Now imagine looking at it through a very dirty window pane with the center completely obscured by gray paint. Try to imagine your closet on the other side of that window. As far as I was concerned, the blouse was gone, so I assumed that someone took it out of the closet. Apparently that makes me paranoid. "Not being able to find your clothes might make anyone paranoid," I snapped. "Leave my stuff the heck alone!" So we fought about the red blouse. She scolded me like a naughty child, and I threw a tantrum pulling clothes from my closet.

I run through all the other mistakes I made this week. Dropped my pills and couldn't find the tiny round one. Poured

Published online January 5, 2011 salad dressing on my mashed potatoes. In all fairness, lettuce and potatoes look the same through that dirty window pane. Lost my hearing aid-again. Stepped on my glasses-again. Dumped my purse out on the ground in frustration trying to find the above-mentioned lost items. You can't really call that a tantrum, can you?

The nurse returns alone. "I need to...blah blah blah, OK?" she mumbles to her clipboard. "OK," I say, without any idea what she's asking of me. Using the available clues, I guess she wants to take blood or a blood pressure. I roll up my sleeve, but she looks at me and does not take my offered arm. Guess I guessed wrong. "I need to ask you some questions," she shouts. "I want you to remember these three objects-a red ball, a blue skate and a green apple." Red ball, blue skate and green apple. Wait-what did she ask me just now? "You don't know your name?" she asks again. "Of course I know my name," I snap. She waits. I waitthen I say it. She checks a box. I concentrate intensely, afraid to ask her to repeat her questions. How can I remember the three objects when I have to concentrate so hard to hear the next question? The objects have flown the coop. One flew over the cuckoos' nest, I think, humoring myself. Why doesn't she ask me about my grandkids? I keep up to date on things I care about. I don't care who's running the country. What color was that ball? I know she's going to ask me. I miss another question. What was the second object? I'm smart enough to know that I have dismally failed my mental status exam.

The nurse leaves and returns with the doctor and my daughter. What were those damn objects she asked me to remember? I know for sure that this can't be good; ganging up on me. I concentrate on the doctor's voice, though he is talking not to me, but about me. "Blah blah blah...medication." What medication? "Risk of sudden death...blah, blah...worth it to control behavior... blah blah blah." What? WHAT?

How about a pill that makes lettuce green and potatoes white again? How about cleaning the damn window pane so people's faces, new and old, aren't stored as Picasso paintings? How about I get back everything that life on earth has taken away from me at 90, in full color and technosound? How about I see, hear and walk unassisted again? Even if I knew, I'd still not give a hoot about who's running the country. From this point on, my prayer is for sudden death, leaving my failed body and the cuckoo's nest behind.

Acknowledgements: I would like to acknowledge Louise Aronson, MD, MFA, and Jennifer Best, MD, Deputy Editors for the Journal of General Internal Medicine, for their assistance in editing my essay.

Corresponding Author: Tracey Delaplain, MD, FACOG; Center for Women's Health, 6536 So. McCarran Blvd, Suite B, Reno, NV 89509, USA (e-mail: Fourplains@sbcglobal.net). 